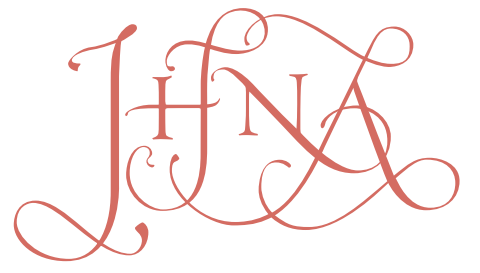

JOURNAL OF HISTORIANS OF NETHERLANDISH ART

Volume 8, Issue 2 (Summer 2016)

European Research Council

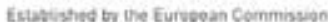

Supporting top researchers

from anywhere in the world

\title{
Grace, Genius, and the Longinian Sublime in Rembrandt's Aristotle with a Bust of Homer
}

Joanna Sheers Seidenstein

joanna@seidenstein.com

Recommended Citation:

Joanna Sheers Seidenstein, "Grace, Genius, and the Longinian Sublime in Rembrandt's Aristotle with a Bust of Homer," JHNA 8:2 (Summer 2016), DOI: 10.5092/jhna.2016.8.2.5

Available at https://jhna.org/articles/grace-genius-longinian-sublime-rembrandt-aristot-

le-with-a-bust-of-homer/

Published by Historians of Netherlandish Art: https://hnanews.org/

Republication Guidelines: https://jhna.org/republication-guidelines/

Notes: This PDF is provided for reference purposes only and may not contain all the functionality or features of the original, online publication. This PDF provides paragraph numbers as well as page numbers for citation purposes.

ISSN: 1949-9833 


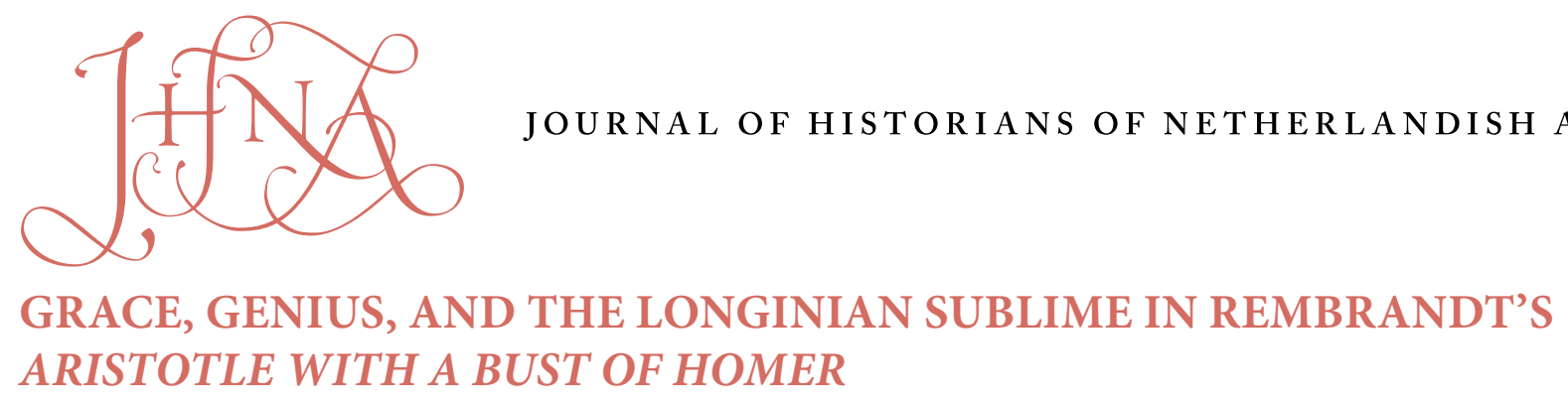

\section{Joanna Sheers Seidenstein}

In his 1637 book, De pictura veterum, Franciscus Junius makes the case that natural talent rather than learned theory plays the greater part in creative achievement, a view he grounds in the ancient literary treatise Peri hypsous, traditionally attributed to Longinus and known since the eighteenth century as On the Sublime. By the 1650s, Junius's discussion of the Longinian sublime, or grace, would have taken on new significance in light of the growing interest, in and beyond the Dutch Republic, in codified rules - much of it revolving around Aristotle's Poetics. Against this trend, Rembrandt produced his Aristotle with a Bust of Homer of 1653 (New York, Metropolitan Museum of Art). In it he presents Aristotle-author of the earliest extant and most influential work of literary theory — at a moment of recognition that his rules are ultimately insignificant in comparison to natural genius, which his forebear Homer above all others possessed. Rembrandt thus pictorializes the sublime and, with the heavy gold chain draped across Aristotle's chest, articulates the view attributed to the artist by later critics: that in pursuit of the height of excellence in art and literature one ought to bind oneself to one's natural gifts, rather than to theoretical rules. Rembrandt does not illustrate Junius's text, but may have found in the scholar's invocations of Longinus an affirmation of his own long-held understanding of genius. DOI: 10.5092/jhna.2016.8.2.5

In memory of Walter Liedtke

Adhering to the practice he had adopted, he was prepared to challenge our rules of art, of anatomy, human proportions and perspective, arguing against the use of antique sculptures, against Raphael's draftsmanship and the systematic training of young artists, and against the academies, so vital to our profession, asserting that one should bind oneself solely to nature and observe no other rules. -Joachim von Sandrart, Teutsche Academie (1675)

These well-known remarks about Rembrandt's supposed rejection of the "rules of art" represent not the anachronistic view of a distant commentator, but instead, as Perry Chapman and Eric Jan Sluijter have demonstrated, the informed (if exaggerated) reaction of a fellow painter to the eccentric artistic persona that Rembrandt in fact crafted and the naturalistic mode of representation he indeed practiced and promoted in opposition to established standards of idealization. ${ }^{2}$ Sandrart's words also reflect, more broadly, a longstanding debate about the place of rules in artistic and 


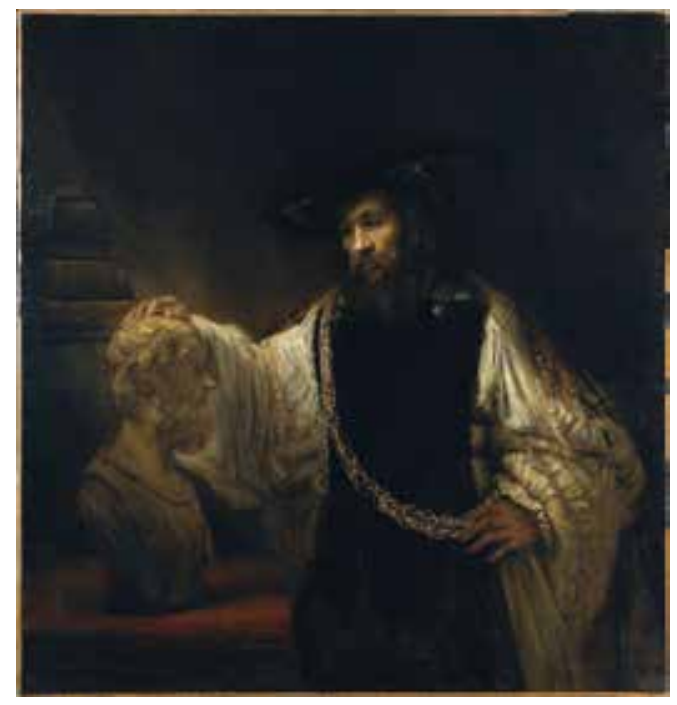

Fig. 1 Rembrandt van Rijn (1606-1669), Aristotle with a Bust of Homer, 1653 , oil on canvas, 143.5 x $136.5 \mathrm{~cm}$. New York, Metropolitan Museum of Art, Purchase, special contributions and funds given or bequeathed by friends of the Museum, 1961 (artwork in the public domain)

literary achievement, to which, as I shall propose, Rembrandt himself contributed with his Aristotle with a Bust of Homer of 1653 (fig. 1). ${ }^{3}$ Throughout the seventeenth century, Dutch writers addressed the question of the relative importance of innate ability ("nature") and learned theory or rules ("art"), whether with regard to the visual or literary arts, or, as was often the case, with implications for both. An early and especially illuminating example is Franciscus Junius's discussion in his book De pictura veterum (The Painting of the Ancients), published in Latin in 1637 and in English and Dutch translations, carried out by the author himself, in 1638 and 1641, respectively. In this text-not a source for Rembrandt but an indicator of the ideas and ideals of his contemporaries-Junius makes the case that natural talent plays the more significant part in producing truly great art, a view he grounds in Longinus's Peri hypsous, in which sublime achievement is largely attributed to in-born (or divinely bestowed) genius unfettered by artificial rules. $^{5}$ Analyzing Rembrandt's picture in relation to Junius's invocations of the Longinian sublime and the broader nature versus rules debate, I interpret the painting as a narrative in which Aristotle, author of the earliest extant and most influential work of literary theory, recognizes that his rules are ultimately insignificant in comparison to innate genius, which his forebear Homer above all others possessed. ${ }^{6}$ In this work Rembrandt pictorializes the sublime and, with the golden chain that hangs across the philosopher's chest, articulates the view that Sandrart would later attribute to the artist: that in pursuit of the height of excellence in creative achievement, one ought "to bind oneself" to nature-meaning one's natural gifts—rather than to codified rules.

2 Although destined for the Sicilian nobleman Antonio Ruffo, Aristotle with a Bust of Homer represents, as Julius Held established in 1969 in his seminal study of the picture, a subject of Rembrandt's own devising - one that is unique in the history of art and that relates, naturally, to the artistic and intellectual climate of his own milieu. ${ }^{7}$ A letter of June 19, 1654, indicates that the picture, reliably inscribed 1653, left Amsterdam nearly six months after its latest possible completion. ${ }^{8}$ The work therefore most likely remained for a significant period of time in the artist's studio, where it could have enjoyed an audience composed of fellow Dutch artists and art lovers, among them the amateur poet and playwright Jan Six, whom Rembrandt portrayed in 1654. ${ }^{9}$ In any case, there is no evidence that its subject was predetermined by or even conveyed in advance to Ruffo, whose household first registered it on September 1, 1654, as "a half-figure 
of a philosopher made in Amsterdam by the painter Rembrandt (apparently Aristotle or Albertus Magnus)." ${ }^{10}$ In a letter of November 1662, however, Ruffo explicitly referred to the work as the "Aristotile," making clear that by this point he had gained clarity about what it represented, presumably through exchanges about the two additional paintings Rembrandt sent to Ruffo in 1661: Alexander the Great (lost ${ }^{11}$ ) and Homer (The Hague, Mauritshuis). ${ }^{12}$

The patron's initial uncertainty about the subject is understandable given the small but varied visual tradition surrounding the philosopher's portrayal. Yet, as Walter Liedtke demonstrated in 2004, one tradition called for his representation with a beard, long hair, hat, and, according to at least one extant work-Joos van Wassenhove's Aristotle, part of the series of famous men he produced for the ducal palace of Federico da Montefeltro at Urbino in the 1470s (fig. 2) - a ring on the end of a finger and a raised right arm. ${ }^{13}$ Whether Rembrandt was aware of this work through a drawing or copy or knew another like it, the resemblance between it and his own representation strongly suggests that he made a distinct effort to make Aristotle recognizable. Accordingly, his choice of protagonist bears direct significance on the meaning of the picture. The one weakness of Held's highly influential and still prevailing view that the painting depicts a conflict between eternal fame (represented by Homer) and worldly success (represented by the chain, in his view a collar of service bearing the portrait of Alexander the Great) is that for such a program, other historical, even anonymous, figures might have served equally well. ${ }^{14}$ Instead we must seek an understanding in which Aristotle, his admiration for Homer, and thus his identity as a literary theorist are central.

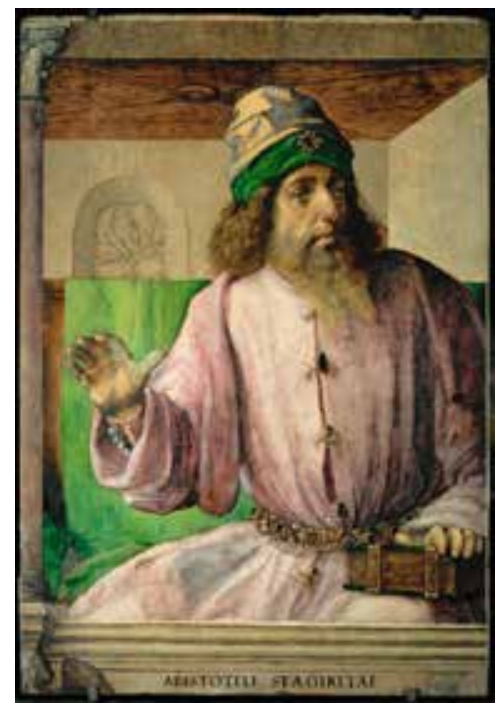

Fig. 2 Joos van Wassenhove (active 1460-1480), Aristotle, ca. 1476, oil on panel, $104 \times 68 \mathrm{~cm}$. Paris, Musée du Louvre (artwork in the public domain; photo: Erich Lessing/Art Resource, N.Y.)

Held's analysis of the Aristotle eclipsed another published one year earlier by Jan Emmens, who in fact associated the painting with nature and theory. ${ }^{15}$ Emmens's interpretation appeared as part of his major study of Rembrandt's reception, in which he proposed that the artist was not antipathetic to rules but simply unaware of the particular "classicistic" principles Sandrart and others anachronistically accused him of rejecting. ${ }^{16}$ According to Emmens, until the 1670s these rules were unknown in the Dutch Republic, and there existed no perception of opposition between nature and theory; instead the artist and his contemporaries believed in the equal importance of nature, teaching, and practice - an ancient triad allegorized in Emmens's view by Rembrandt's 
picture, with Aristotle representing teaching, or doctrine, Homer nature, and Alexander, by virtue of his military exploits, practice. ${ }^{17}$ This triad, however, appears in extremely few seventeenth-century Dutch sources. ${ }^{18}$ Instead, writers of the period-Huygens, Junius, Vossius, Vondel, Vos, and Pels, among others-frequently discussed natural talent and learned rules in contrasting, not complementary, terms. Even if none of them could truly believe solely in one or the other and as much as their remarks were informed by those of their ancient forebears, they were not merely repeating a common topos but earnestly enquiring into what produces great art and literature. This discourse coincided with the increasingly frequent publication and translation of ancient treatises on rhetoric and literature and, by the 1650s, the growing embrace of theoretical principles by contemporary poets and dramatists. Instead of viewing Rembrandt's picture as an illustration of a static concept, I frame it as a contribution to-even against—this trend in contemporary thinking about the place of rules in creative pursuit.

The nature versus rules debate indeed played out most visibly in the later part of the century, specifically in the writings of Jan Vos and Andries Pels. In the preface to the printed edition of his 1667 version of Medea, entitled "Aan de Beminnaars van d'oude en nieuwe Tooneelspeelen," Vos directly questioned the utility - for ancient and contemporary practitioners-of Aristotelian and Horatian literary theories. ${ }^{19}$ Vos's sentiments were in direct opposition to those of Pels, who in 1669 founded a literary society in Amsterdam, aptly named Nils volentibus arduum ("With will, nothing is impossible"), to promote those authors' treatises and the adherence to classical doctrine more broadly. Pels also addressed the question explicitly in 1677 in his free translation of Horace's Ars poetica, in which he frequently makes reference to contemporary poetry and responds directly to Vos. ${ }^{20}$ Here Pels acknowledges that those whom the Muses do not favor cannot compensate entirely through study and practice but emphasizes that so too is achievement impossible with an "uncivilized mind" and that doctrine must help nature "before one can obtain a place amongst the famous ranks of the greatest poets." ${ }^{21} \mathrm{He}$ concludes that "one is not born with art." 22 He reiterates these views in his Gebruik, én misbruik des tooneels (Use and Abuse of Theater) of 1681, in which he famously characterizes Rembrandt as a rule breaker. ${ }^{2}$

That there was already a debate under way much earlier in the century-and that Rembrandt was already insinuated within it-is clear from Constantijn Huygens's vehement discussion of natural talent in the memoir he wrote between 1628 and $1631 .{ }^{24}$ In it he questions the value of treatises on oratory, arguing that any theory or lessons beyond the most basic fundamentals are redundant, even harmful, to natural talent, to which all clear and compelling expression is owed. ${ }^{25}$ Similarly, of the young Rembrandt and Jan Lievens, he comments that these artists owe nothing to their teachers and that even without their lessons they would have been seized by the urge to paint and reached the same heights. ${ }^{26}$

7 In De pictura veterum, Junius offers an extensive treatment of the question. On one hand he celebrates and promotes theory, freely applying ancient principles of rhetoric and poetry to painting. Yet he ultimately identifies natural talent as the chief source of artistic perfection-the endowment of a picture with an indefinable, special quality that succeeds in moving the beholder. To refer both to this perfection of art and to an individual's capacity to produce it, he uses the term grace (gratie and occasionally bevalligheydt in the Dutch edition, gratia, venustas, and ingenio in the Latin). ${ }^{27}$ While he draws from Cicero, Quintilian, Pliny, and Plutarch, all of whom speak 
of an indescribable quality of rhetoric or art, he is informed most substantially by Longinus's discussion of the sublime (hypsous, literally height) - the pinnacle of achievement that brings human endeavor closer to the work of prophets and gods and results in a powerful effect that "sways every reader whether he will or no." ${ }^{28}$ What distinguishes his remarks, and in turn Junius's, is the emphasis on the direct relationship between the excellence of the work and the character, or spirit, of its maker-effectively an articulation of the modern concept of creative genius. ${ }^{29}$

Longinus himself believes in the combination of natural ability and rules (his treatise, after all, largely concerns technique), but he emphasizes that it is from the former that arise the two most important sources of sublimity (the capacity to conceive great thoughts and the compelling treatment of emotions), and he is adamant that rules must not limit or constrain genius. ${ }^{30}$ Drawing a contrast between flawless but mediocre practitioners on the one hand and erring but great poets on the other, he praises the latter-Homer chief among them-and upholds as the highest quality of a writer "that impetuous, that god-gifted genius, which chafed against the restraints of law." ${ }^{31}$

9 In equating grace with the Longinian sublime, Junius employed a term that had deeply rooted religious meaning and, in the Dutch Republic in the early years of the seventeenth century, especially charged associations. ${ }^{32}$ The nature of divine grace was one of five articles around which the conflict between Remonstrants and Counter-Remonstrants centered, a conflict Junius experienced firsthand during his brief employ as a minister at Hillegersberg in $1617 .{ }^{33}$ Both sides believed that grace was bestowed solely and freely by God and that it cannot be earned, but while the former understood man to have been allotted the free will to accept or refuse grace, the latter embraced a strict definition of irresistible grace, which, according to the Counter-Remonstrance of 1611:

works so powerfully in the hearts of God's elect, that He illumines their minds, transforms and renews their wills, removing the heart of stone and giving them a heart of flesh, in such a manner that by these means they not only receive power to convert themselves and believe but also actually and willingly do repent and believe. $^{34}$

10 Sixteenth-century Italian writers had, however, already established grace as a personal attribute and aesthetic quality. ${ }^{35}$ In his highly influential Libro del Cortegiano (1528), Baldassare Castiglione defines grazia as the overarching quality of charm and ease to which the courtier must aspire, particularly with regard to his eloquence as a speaker. ${ }^{36}$ For Castiglione, grace can be studied and learned, but, as he famously writes, all signs of effort must be masked by "a certain nonchalance" (sprezzatura), such that one's orations will seem to be "springing rather from nature and truth than from study and art." ${ }^{37}$ Cesare Ripa, however, in his Iconologia (first published 1593) explicitly identifies grace as a natural gift. His entry on Gratia describes a beautiful woman wearing pearls that "shine and please as a rare and secret gift of nature, like grace, which is a certain special charm in men that moves and ravishes the mind to love, and by stealth engenders liking and benevolence." ${ }^{38}$ Vasari, too, in his Vite (1550/68), asserts that grazia cannot be taught. Applying the concept of grace to painting, he refers to a quality of the artist's performance akin to virtuosity: characterized by facility, boldness, and an absence of laboriousness and excessive study. ${ }^{39} \mathrm{He}$ writes: "Very great is the obligation that is owed to Heaven and to Nature by those who bring their 
works to birth without effort and with a certain grace which others cannot give to their creations either by study or imitation." 40

11 Junius inherited these definitions of grace, but through his direct study of Peri hypsous he gives it new significance, ultimately formulating a new definition of artistic genius. Introducing the term in the first of the three books that comprise De pictura veterum, Junius frames grace as the ultimate goal of artistic endeavor, that which distinguishes a great master or "perfect Artist" and brings him "everlasting fame." ${ }^{41}$ Here he follows Longinus's characterization of the sublime as the supreme height of achievement, by which "the greatest poets and prose-writers have gained eminence, and won themselves a lasting place in the Temple of Fame." ${ }^{42}$

12 Interwoven with Junius's discussion of grace throughout the three books are remarks about natural ability and rules. ${ }^{43}$ Like Longinus, he maintains that both are necessary, at one point quoting the ancient theorist's own remark that "perfection consisteth in a mutuall coherence of these two." ${ }^{44}$ Nevertheless, Junius repeatedly asserts the greater importance of nature, writing in Book 1, for example, that "nature can doe much without Doctrine, where Doctrine on the contrary cannot be without Nature." ${ }^{45}$ In the same passage, he directly addresses the subject of grace with regard to natural inclination, writing that "every Artificer hath a peculiar Grace in his works, agreeing with the constitution of his nature." ${ }^{46}$ Later Junius, again quoting Longinus, emphatically states that "magnificent thoughts come by nature, and cannot be taught." ${ }^{47}$ In the same section he makes the significant point that grace is the domain of "great minded men" who are "of an exceeding great spirit, or at least upon all occasions entertaine great thoughts, and stately imaginations." ${ }^{48}$ In a similar vein, he also excuses errors made by great practitioners, writing that "somthing must be indulged unto the wits of great Masters" and offers as an example Homer, who, according to Horace, "doth somtimes slumber and oversee himselfe." ${ }^{49}$

13 It is in the third book that Junius presents a sustained analysis of grace, equating it with the sublime. In chapter 6, he offers a definition that directly echoes Longinus's characterization of the sublime as the culminating effect of excellence in five distinct areas (in Junius's case, Invention, Proportion, Color, Life, and Disposition):

The consummation of a picture consisteth chiefely therein, that these five heads concurring, and lovingly conspiring, should breath forth a certain kinde of grace, most commonly called 'the aire of the picture:' which in it selfe is nothing else but a sweet consent of all manner of perfections heaped up in one piece: the best collection of the best things..$^{50}$

14 Reiterating that grace "readily and freely proceeding out of the Artificers spirit, cannot be taught by any rules of art: no more can assiduity of importunate studies helpe us to it," Junius warns against "an unseasonable and over curious nicenesse of studying." ${ }^{11}$ Here citing Plutarch, he again names Homer, and other poets and painters, in order to contrast belabored effort with the ease and freedom that characterizes true grace:

Plutarch doth likewise make a distinction betweene the fore-mentioned Grace and this same bold Facilitie: "the verses of Antimachus," sayth he, "and the pictures 
of Dionysius...seeme to be forcibly expressed and too much belaboured: but Nichomachus his pictures and Homer his verses have this also besides all the other efficacie and grace which is in them, that you would thinke them made out of hand with much ease." 52

15 These remarks recall another Junius makes earlier in his text, in Book 2, where he, once again drawing from Longinus, encourages negligence, writing that "it addeth a singular grace to the worke, that there should sometimes appeare a certaine kinde of neglect [een sekere soorte van onachtsaemheyd] in most excellent Pictures [gheestighste schilderijen]. ${ }^{53}$ In that passage, his use of the term grace (bevalligheydt in the Dutch edition) comes closer to Castiglione's discussion of sprezzatura and seems to refer to an artist's or poet's virtuosity, but in his discussion in Book 3 Junius makes clear that his understanding of grace goes beyond the illusion of ease to denote a quality of art with an effect beyond words and a source beyond effort and rules:

Pictures which are judged sweeter then [sic] any picture, pictures surpassing the apprehension and Art of man, workes that are sayd to be done by an unspeakable way of Art, delicatly, divinely, unfeisably, etc. insinuate nothing els but that there is something in them which doth not proceed from the laborious curiositie prescribed by the rules of Art, and that the free spirit of the Artificer marking how Nature sporteth her selfe in such an infinite varietie of things, undertooke to doe the same. ${ }^{54}$

Junius thus directly opposes the rules of art and the free spirit of the artist.

16 By 1653, this discussion of grace would have taken on new significance in light of the growing interest in codified rules in and beyond the Dutch Republic, much of it revolving around Aristotle's Poetics. The publication in 1643 of a revised edition of Daniel Heinsius's 1610/11 Latin translation of and commentary on the Poetics and in 1647 of Gerardus Vossius's monumental study of the ancient text had international impact, spreading a refined understanding of Aristotelian literary theory throughout Europe. ${ }^{55}$ The greatest Dutch playwright of the period, Joost van den Vondel, in consultation with Vossius, had already shown an interest in Aristotelian drama as early as 1639 and would continue to refer to the ancient philosopher's treatise for his work, even citing his precepts in the foreword to his 1659 tragedy Jeptha. ${ }^{56}$ Rembrandt himself would have the opportunity in 1648, if not before, to become familiar with the strictures of Aristotelian dramatic theory, when he produced the etched frontispiece for Jan Six's Medea, as pure an Aristotelian tragedy as had ever been written. ${ }^{57}$ While Vondel's own attitude toward theory cannot be characterized so simply-he was never a pedantic follower of rules and his adaptation of ancient theory was not an end unto itself-he nonetheless played a role in promoting poetic theory through his plays, as well as through his Aenleidinge ter Nederduitsche dichtkunst of 1650 and his 1654 translation of Horace's Ars poetica, in which he acknowledges the "nurture of rules." 58 Thus the work of Andries Pels in and after the late 1660s did not initiate so-called "classicistic literary theory" in the Netherlands but rather developed and expanded an effort some years in the making. ${ }^{59}$

17 Against this trend Rembrandt produced his Aristotle with a Bust of Homer. Just as knowledge of Aristotle's Poetics and likewise the philosopher's reputation as a literary theorist was at this mo- 
ment as widespread as it ever had been, the Homeric epics, long familiar through their circulation in Latin translation, were widely read by Dutch audiences. By 1611 the entirety of the Odyssey and portions of the Iliad, along with ancient accounts of the poet's life, had been translated into Dutch, and in the 1650s new Dutch translations of both of his epics were undertaken. ${ }^{60}$ Homer himself was a long-standing paragon of natural or God-given genius-one who occasionally erred and broke rules, as Longinus, Horace, Junius, and various other ancient and early modern writers noted-and he was often portrayed as a divinely inspired poet-seer. In Raphael's Parnassus, for example, Homer raises his blind eyes to suggest the heavenly source of his gift. This composition was widely known through Marcantonio Raimondi's engraving, which served as the basis for Rembrandt's own 1652 drawing of Homer for Jan Six’s album amicorum.

18 The rare joint appearance of Aristotle and Homer in Rembrandt's painting would have undoubtedly brought to mind their opposing associations with theory and with genius. Moreover, in the Poetics itself, Aristotle grapples with the question of nature and rules as concerns Homer, observing his "transcendent excellence" and even asking whether his perfection stems "from art or natural genius." ${ }^{61}$ Addressing this tension between Aristotle's effort to codify literary achievement into a set of principles and his understanding of Homer's natural gifts, Rembrandt constructs a narrative in which the philosopher is overcome by the poet's genius and recognizes the limitations of his own rules. Appropriately he portrays a physical experience, a direct encounter between poet and theorist. Aristotle is not reading Homer's epics but standing before and touching the bust, which, rendered with loose brushstrokes and warm tones, looks almost like sculpture come to life-as if he were in the poet's actual presence. His expression and his gaze beyond the bust convey the overwhelming thoughts and emotions - the transport of the mind - that this encounter has inspired, while the warm light that appears to move across his face is suggestive of revelation. ${ }^{62}$ In all of these regards, Rembrandt's presentation of Aristotle anticipates his Saint Matthew and the Angel of 1661 (fig. 3). Like the saint who experiences divine illumination-receiving the word of God through the angel who whispers in his ear and physically touches his shoulder-the philosopher experiences awe at Homer's genius and its God-given source. Aristotle's is not a religious encounter, but the artist employs the same pictorial language to represent the sublime.

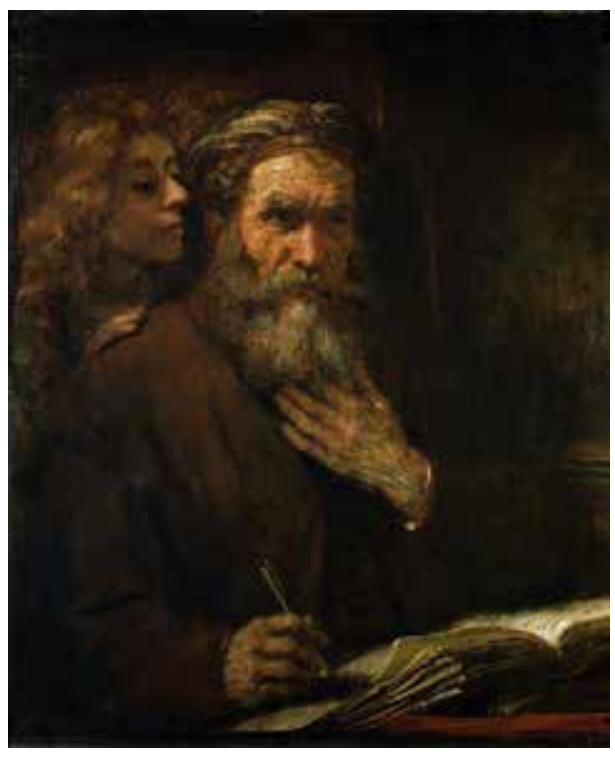

Fig. 3 Rembrandt van Rijn (1606-1669), Saint Matthew and the Angel, 1661 , oil on canvas, $52 \times 66 \mathrm{~cm}$. Paris, Musée du Louvre (artwork in the public domain; photo: Erich Lessing/Art Resource, N.Y.) 
Rembrandt further pictorializes the experience of the sublime with the gold chain. As Christian Tümpel elucidated, one of Rembrandt's chief pictorial tactics was to take a highly symbolic element and work it into his composition as naturally and plausibly as possible-to name an obvious example, the gilt Cupid sculpture that alludes to bound love in the Danaë (St. Petersburg, State Hermitage Museum) ${ }^{63}$ In my view, the chain in the Aristotle is another, more complex example of this practice. On one level it is, as Held demonstrated, a collar of service bearing the portrait medallion of Alexander the Great, whom Aristotle once served as tutor. (The fact that Rembrandt subsequently painted a Homer and an Alexander to join the Aristotle in Ruffo's collection supports this. In addition, similar chains with medallions appear in a number of works by Arent de Gelder, where they clearly indicate a figure's service to a ruler. ${ }^{64}$ ) At the same time, the ambiguity of the portrait on the medallion (fig. 4), which has continually given rise to debate about whether it represents Alexander or Minerva, is in my view deliberate-not a misunderstanding of Greek coins that feature the helmeted head of Minerva (or Athena) on one side and Alexander's name on the other (fig. 5) but a clever allusion to their dual imagery. ${ }^{65}$ In Rembrandt's picture, the medallion is plausibly incorporated into the picture as a portrait of Alexander, but it also operates metaphorically as a representation of Minerva, goddess of wisdom and protector of the liberal arts, who bestows on the poet divine inspiration and genius. Notably, in his book Junius associates Minerva with in-born talent, quoting Cicero's remark that "nothing can be decent and comly in spight [meaning in opposition to] (as the common saying is) of Minerva, that is, our nature not giving way to it." 66

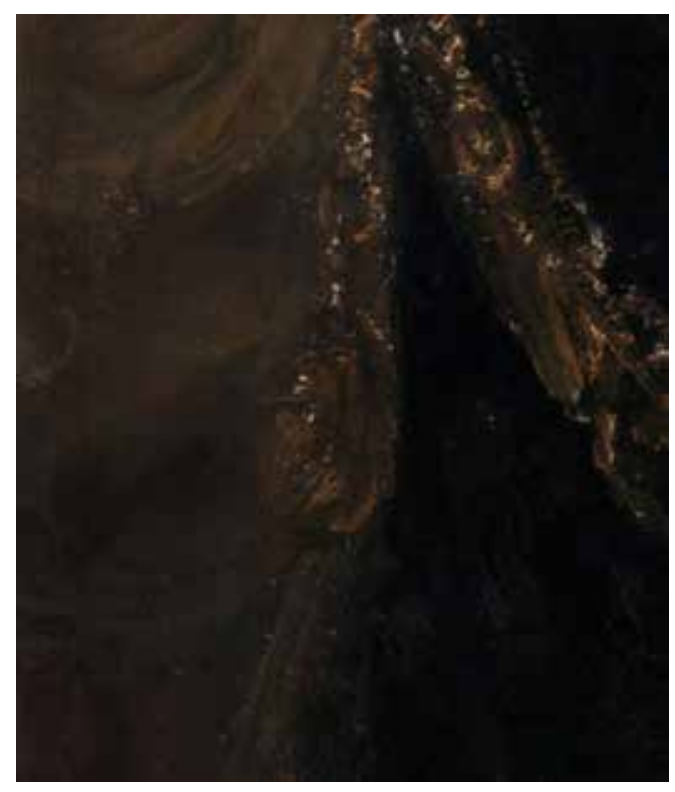

Fig. 4 Detail of fig. 1

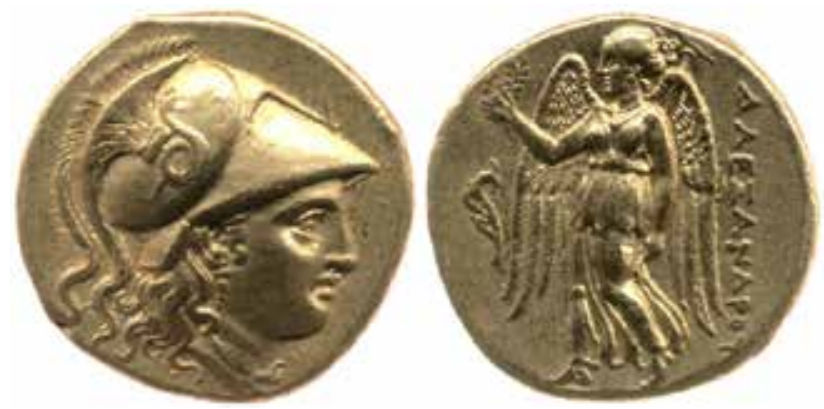

Fig. 5 Greek coin with the head of Athena (obverse) and the standing figure of Nike and inscription of Alexander's name (reverse), ca. 310-275 BCE. London, British Museum (artwork in the public domain; photo: @Trustees of the British Museum)

This understanding of the medallion permits association of the chain directly with grace and with positive connotations of captivation and bondage. A few lines before his invocation of Minerva, chains serve Junius as a metaphor for the overwhelming power of grace:

Having now seene alreadie wherein the chiefe comelinesse of Grace doth consist, and how by a glorious conquest it doth sweetly enthrall and captivate [in the Dutch edition, "soetelick gevetert ende gevangen houdt"] the hearts of men with the lovely chaines [in the Dutch, "de helde," an 
archaic term for bondage] of due admiration and amazement. ${ }^{67}$

21 In Italy viewers of Rembrandt's picture came to understand the chain in precisely these terms. As Xavier Salomon and Helen Langdon have shown, in 1673, twenty years after Rembrandt painted the Aristotle, the Italian artist Giacinto Brandi sent to Antonio Ruffo a now lost depiction of an artist at work on a painting of the giant Tityus chained to a rock. ${ }^{68}$ With regard to this work, which Ruffo understood to have been produced in direct emulation of Rembrandt's Aristotle, Brandi expressed in a letter to his patron that just as Tityus was chained, so he, the artist, was captivated by Ruffo's "rare personal qualities and endearments." ${ }^{69}$ Even in this undeniably negative context - an image of actual bondage - the chain serves as a metaphor for the captivating awe that an individual's grace could inspire-the very theme Rembrandt treats in his picture.

22 The chain bears, however, yet another layer of significance. In the seventeenth century, the sublime encompassed two contradictory experiences: to be carried away by powerful effects of language or imagery such that the listener/reader or viewer loses himself in what is represented, but also to recognize that this overwhelming effect is the product of the poet's or artist's performance, knowledge of which itself astounds and moves. In the painting, Aristotle touches the chain with its medallion with one hand and the bust of Homer with the other, linking the poet's grace with its source, articulating the view that one should bind oneself to God-gifted nature. By casting in this role none other than the author of the Poetics, Rembrandt makes a powerful statement, one with which he was long associated.

23 When Sandrart remarks that Rembrandt asserted that one should "bind oneself solely to nature," he addresses not just the artist's preference for the lifelike over the idealized but also his belief in genius over rules. Similarly, when Andries Pels writes about Rembrandt in his treatise on theater in 1681, he also employs the term nature to refer both to the lifelike and to natural inclination: "Sagging breasts,/Contorted hands, even the marks left by stays/On the stomach, of garters on the leg,/They must all be copied else nature was not satisfied,/At least, his nature, which tolerated neither rules/Nor principles of proportion in the human figure [emphasis mine]." ${ }^{\text {"70 }}$ At the end of this passage, Pels also uses the term binden with regard to rules, remarking that "the nobler the spirit, the wilder it will become, if it binds itself to no foundation and no cord [snoer] of rules, but rather endeavors to look within itself for knowledge." 71

24 Rembrandt's picture is not a critique specifically of Aristotelian precepts or of all rules of poetry and painting (even he surely acknowledged the value of some), but of what he must have perceived as his contemporaries' increasing reliance on theory and failure to recognize geniusamong poets and painters, whose kinship had just been celebrated at the feast of St. Luke's Guild in Amsterdam in October 1653. Certainly, the work is not only a narrative and allegory about poetic genius but also a performance-in paint-of grace. The subtle but affecting expression of Aristotle, the sensuous depiction of his gauzy robe and glinting chain entrance the viewer yet ultimately draw attention to the artist himself, his artifice, his genius. Rembrandt does not illustrate Junius's text, but by 1653, he may have found in the scholar's invocations of Longinus a prestigious ancient model with which to affirm his long-held understanding of truly great art-one that had nothing to do with bodily beauty or strict aesthetic ideals and that was, according to the ancient theorist, to be lauded high above laborious and pedantic achievement: 
Yet, though I have myself noted not a few faulty passages in Homer and in other authors of the highest rank, and though I am far from being partial to their failings, nevertheless I would call them not so much wilful blunders as oversights which were allowed to pass unregarded through that contempt of little things, that "brave disorder," which is natural to an exalted genius. ... Let us take an instance: Apollonius in his Argonautica has given us a poem actually faultless.... And what then? Would you rather be a Homer or an Apollonius? ${ }^{72}$

\section{Acknowledgements}

I am grateful to have had the opportunity in 2014 to discuss my research with Walter Liedtke, who generously offered me his encouragement and whose scholarship has provided an inspiring example. With admiration I dedicate this essay to his memory. My heartfelt gratitude goes to the editors of this issue, Stijn Bussels and Bram van Oostveldt, to my dissertation adviser, Mariët Westermann, to my colleagues at the Frick, especially Xavier F. Salomon, Susan Grace Galassi, Aimee Ng, Margaret Iacono, Esmée Quodbach, Adam Eaker, and Aaron Wile, and to my awe-inspiring husband, Marc Seidenstein. I also warmly acknowledge the support of the European Research Council program "Elevated Minds" and the Netherlands Institute for Advanced Studies.

Joanna Sheers Seidenstein is the 2015-17 Anne L. Poulet Curatorial Fellow at the Frick Collection and a PhD candidate at New York University's Institute of Fine Arts, where, from 2009 to 2014, she held the Kaplan-Fisch Fellowship in the Connoisseurship of European Paintings. She is writing a dissertation on Rembrandt's treatments of themes from classical antiquity. joanna@seidenstein.com

\section{List of Illustrations}

Fig. 1 Rembrandt van Rijn (1606-1669), Aristotle with a Bust of Homer, 1653, oil on canvas, 143.5 x $136.5 \mathrm{~cm}$. New York, Metropolitan Museum of Art, Purchase, special contributions and funds given or bequeathed by friends of the Museum, 1961 (artwork in the public domain)

Fig. 2 Joos van Wassenhove (active 1460-1480), Aristotle, ca. 1476, oil on panel, 104 x $68 \mathrm{~cm}$. Paris, Musée du Louvre (artwork in the public domain; photo: Erich Lessing/Art Resource, N.Y.)

Fig. 3 Rembrandt van Rijn (1606-1669), Saint Matthew and the Angel, 1661, oil on canvas, 52 x 66 cm. Paris, Musée du Louvre (artwork in the public domain; photo: Erich Lessing/Art Resource, N.Y.)

Fig. 4 Detail of fig. 1

Fig. 5 Greek coin with the head of Athena (obverse) and the standing figure of Nike and inscription of Alexander's name (reverse), ca. 310-275 BCE. London, British Museum (artwork in the public domain; photo: $\odot$ Trustees of the British Museum) 
${ }^{1}$ Joachim von Sandrart, L'Academia Todesca della Architectura, Scultura \& Pittura: Oder Teutsche Academie der edlen Bau-, Bild-, und Mahlery-Künste (Nuremburg: Jacob Sandrart; Frankfurt: Matthaei Merians; printed by Johann-Philipp Miltenberger, 1675), vol. 1, part 2, book3, chapt. 22, p. 326: "Demnach bliebe er beständig bey seinem angenommenen Brauch, und scheuete sich nicht wider unsere Kunst-Reglen, als die Anatomia und Maas der menschlichen Gliedmaßen, wider die Perspectiva und den Nutzen der antichen Statuen, wider Raphaels Zeichenkunst und vernünftige Ausbildungen auch wider die unsere Profession höchst-nöhtigen Academien zu streiten, und denenselben zu widersprechen, vorgebend, daß man sich einig und allein an die Natur und keine andere Reglen binden solle." I quote most of Ernst van de Wetering's translation of this passage in Rembrandt: A Genius and His Impact, exh. cat., ed. Albert Blankert et al. (Melbourne: National Gallery of Australia, and Sydney: Art Exhibitions Australia/Zwolle: Waanders, 1997), 63, but I return to a slightly more literal translation of the last phrase.

${ }^{2}$ Sandrart was in Amsterdam between 1637 and 1645. H. Perry Chapman, Rembrandt's Self-Portraits (Princeton, N.J.: Princeton University Press, 1990),132-36; and Chapman, "Rembrandt, Van Gogh: Rivalry and Emulation," in Rembrandt: Three Faces of the Master, ed. Benedict Leca (Cincinnati Art Museum, 2008), 17-49; Eric Jan Sluijter, "Rembrandt and the Rules of Art Revisited," Jahrbuch der Berliner Museen 51 (2009): 121-29; and Sluijter, Rembrandt and the Female Nude (Amsterdam: Amsterdam University Press, 2006), esp. 195-97 and 212-19.

${ }^{3}$ Sluijter, Rembrandt and the Female Nude, 217, discusses Sandrart's text in relation to this longstanding debate. For an extensive account of the literature on Rembrandt's picture, see Walter Liedtke, Dutch Paintings in the Metropolitan Museum of Art (New York: Metropolitan Museum of Art/New Haven and London: Yale University Press, 2007), 629-54; and, in updated but abbreviated form, at http://www.metmuseum.org/collection/the-collection-online/search/437394. Additional discussions of the picture can be found in Philipp and Raina Fehl's introduction to the critical edition of Junius's Painting of the Ancients of 1638, The Literature of Classical Art, vol. 1 ed. Keith Aldrich and P. and R. Fehl (Berkeley, Los Angeles, and Oxford: University of California Press, 1991), xlviii-xlix and opposite fig. 16; Xavier F. Salomon and Helen Langdon, "Of Men and Mechanical Doves: Salvator Rosa's Archytas for Antonio Ruffo," Boletín del Museo del Prado 28, no. 46 (2010): 22-38; Jonathan Bikker et al., Rembrandt: The Late Works, exh. cat. (London: National Gallery, and Amsterdam: Rijksmuseum, 2014), 216-18; and Wetering, Ernst van de, $A$ Corpus of Rembrandt Paintings VI: Rembrandt's Paintings Revisited-A Complete Survey (Dordrecht: Springer, 2014).

${ }^{4}$ Franciscus Junius, De pictura veterum (Amsterdam: Johannes Blaeu, 1637); The Painting of the Ancients, in Three Bookes (London: R. Hodgkinsonne, 1638); and De schilder-konst der Oude, begrepen in drie boecken (Middelburg: Zacharias Roman, 1641). In the foregoing I quote Junius's English text, as printed in the critical edition, The Literature of Classical Art, making note of any substantive differences between it and the 1641 Dutch edition.

${ }^{5}$ Longinus, On the Sublime [Peri hypsous], trans. H. L. Havell (London: Macmillan, 1890). For the reception of Peri hypsous before Nicolas Boileau's translation of 1674, see Caroline van Eck, Stijn Bussels, Maarten Delbeke and Jürgen Pieters eds., Translations of the Sublime: The Early Modern Reception and Dissemination of the Peri Hupsous in Rhetoric, the Visual Arts, Architecture and the Theater (Leiden and Boston: Brill, 2012). On Junius and Longinus, see Allan Ellenius, De Arte Pingendi: Latin Art Literature in Seventeenth-Century Sweden and Its International Background (Uppsala and Stockholm: Almqvist \& Wiksell, 1960), 76-78; Colette Nativel, "Le traité 'Du sublime' et la pensée esthétique anglaise du Junius à Reynolds," in Acta conventus neo-latini haf- 
niensis: Proceedings of the Eighth International Congress of Neo-Latin Studies, Copenhagen, 12-17 Aug. 1991, ed. Rhoda Schnur (Binghamton, N.Y.: Medieval and Renaissance Texts and Studies, 1994), 721-30; Judith Dundas, "Franciscus Junius's 'The Painting of the Ancients' and the Painted Poetry of Ovid," International Journal of the Classical Tradition 3 no. 2 (Fall 1996): 159-70; Judith Dundas, Sidney and Junius on Poetry and Painting: From the Margins to the Center (Newark: University of Delaware Press, 2007), 100-101, 106-7, 207; Thijs Weststeijn, Art and Antiquity in the Netherlands and Britain: The Vernacular Arcadia of Franciscus Junius (1591-1677) (Leiden and Boston: Brill, 2015); and Weststeijn's essay in the present issue.

\section{http://dx.doi.org/10.1163/9789004283992}

${ }^{6}$ In their introduction to The Literature of Classical Art, xlvi-xlix, Philipp and Raina Fehl tentatively suggest a connection between Rembrandt's Aristotle and Junius, citing a copy of the double portrait Anthony van Dyck painted of Earl and Lady Arundel about 1639/40 (known as the "Madagascar Portrait," Sussex, Arundel Castle). The undated copy (Kent, Knole House) features a third figure, sometimes identified as Junius, standing in the background with his hand resting on a bust then understood to represent Homer. The uncertainty of the figure's identification and of the circumstances of the work's execution make it impossible to draw any conclusions, but it is worthwhile to note that Junius was in Amsterdam in the 1650s.

Julius S. Held, Rembrandt Studies, originally published as Rembrandt's Aristotle and Other Rembrandt Studies, 1969 (Princeton, N.J.: Princeton University Press, 1991), esp. 12-13.

${ }^{8}$ Jeroen Giltaij, Ruffo en Rembrandt: Over een Siciliaanse verzamelaar in de zeventiende eeuw die drie schilderijen by Rembrandt bestelde (Zutphen: Walburg Pers, 1999), 43-44, 160-61. In the letter, the agent (Cornelis Gijbertsz van Goor) states that he is "now taking the opportunity of the departure to Naples of the ship the St. Bartolomeo," having "delivered to the captain a crate containing the painting." Giltaij notes that this letter was stamped July 20, 1654, which could be the date it was actually sent or the date it arrived in Messina.

${ }^{9}$ Gary Schwartz, Rembrandt, His Life, His Paintings: A New Biography with All Accessible Paintings Illustrated in Color (New York: Viking, 1985),302, suggests that Jan Six might have played some role in the genesis of the picture. Rembrandt portrayed Six twice, in an etching of 1647 and in an oil of 1654. The latter (Amsterdam, Collectie Six) is undated but universally believed to be the one Six recorded in 1654 in a chronostichon in his large Pandora album, and it has long been connected to the concept of sprezzatura, which, as I will discuss below, relates to the Longinian sublime. For the earliest discussion of the portrait in connection with sprezzatura, see Eddy de Jongh, "Review of Hollandse schilders in the gouden eeuw by Bob Haak" Simiolus 15, no. 1 (1985): 67; see also Ernst van de Wetering, Rembrandt: The Painter at Work, revised ed. (Berkeley and Los Angeles: University of California Press, 2009), 161-62, and Marieke de Winkel, Fashion and Fancy: Dress and Meaning in Rembrandt's Paintings (Amsterdam: University of Amsterdam Press, 2006), 122-24.

\section{http://dx.doi.org/10.5117/9789053569177}

${ }^{10}$ Held, Rembrandt Studies, 26, and Giltaij, Ruffo en Rembrandt, 44, 125-26. As Giltaij explains, another annotation of January 8,1657, repeats the Albertus Magnus identification, as do some of the later inventories, but as Liedtke has persuasively argued (Dutch Paintings, 633), these constitute shorthand repetitions of the 1654 entry.

${ }^{11}$ There are numerous reasons for and against associating Ruffo's Alexander with the socalled Man in Armor in Glasgow. Jeroen Giltaij in Rembrandt: A Genius and His Impact, 134, argued against the identification on the basis of the dimensions of the Glasgow work with and 
without the added strips of canvas, the fact that Ruffo's Alexander is described as a seated figure, and the presence of the Glasgow painting in the collection of Sir Joshua Reynolds in 1764, when according to an inventory of 1783 the Alexander was still in Ruffo's collection. Paul Crenshaw, however, is at work on a forthcoming publication in which he, developing an argument he made in 2006 (Paul Crenshaw, Rembrandt's Bankruptcy: The Artist, His Patrons, and the Art Market in Seventeenth-Century Netherlands (Cambridge: Cambridge University Press, 2006), 126, 128, 189n70), presents a new theory concerning the work's provenance and revisits the possibility that the Glasgow painting is indeed Ruffo's Alexander.

${ }^{12}$ Held, Rembrandt Studies, 26; Giltaij, Ruffo en Rembrandt, 43-45, 163-64; and Liedtke, Dutch Paintings, 634, who stresses the significance of this letter, from Ruffo himself, versus inventories made by someone in his employ. Based on these documents and the 1678 inventory of Ruffo's collection, which lists the work as "Aristotile con la sua mano su una testa," (first published in 1916), G. J. Hoogewerff, "Rembrandt en een Italiaansche Maecenas," Oud Holland 35 (1917): 129-48, was the first to identify the Met"s picture, until then referred to as a representation of Virgil, Torquato Tasso, or Pieter Cornelisz Hooft, as the one recorded in Ruffo's collection. ${ }^{13}$ Walter Liedtke, "The Meanings of Rembrandt's Aristotle with a Bust of Homer," in Collected Opinions: Essays in Honour of Alfred Bader, ed. Volker Manuth and Axel Rüger (London: Paul Holberton, 2004), 76, and Liedtke, Dutch Paintings, 629-54. Herbert von Einem, "Rembrandt und Homerus," Wallraf-Richartz-Jahrbuch 14 (1952), 189, was the first to cite the Joos van Wassenhove picture in relation to Rembrandt's. In addition, Held, Rembrandt Studies, 28, 41, noted that ancient accounts of Aristotle described him as a man who wore many rings; de Winkel, Fashion and Fancy, 210 and 319n99, identifies Aelian's Variae historiae as one such source, and further notes several texts, including Junius's Painting of the Ancients, that specify that Aristotle should be depicted with his arm extended. See also Jan Hendrik Jongkees, Fulvio Orsini's Imagines and the Portrait of Aristotle (Groningen: J. B. Wolters, 1960).

http://dx.doi.org/10.5117/9789053569177

${ }^{14}$ Paul Crenshaw, for example, upholds Held's analysis but argues that the picture portrays instead the ancient painter Apelles: Crenshaw, Rembrandt's Bankruptcy, 148-52.

${ }^{15}$ Jan Emmens, Rembrandt en de regels van de kunst (Utrecht: Haentjens Dekker \& Gumbert, 1968), 169-76, esp. 174. The only scholars to endorse Emmens's idea are Pieter J. J. van Thiel, Rembrandt 1669/1969, exh. cat. (Amsterdam: Rijksmuseum, 1969), 64-66; and Keith Aldrich and Philipp and Raina Fehl, who, in their introduction to The Literature of Classical Art, opposite fig. 16, refer to "the union of the genius of Homer and the reason of Aristotle." ${ }^{16}$ Emmens, Rembrandt en de regels van de kunst.

${ }^{17}$ Ibid., 138-45. Emmens does later admit (p. 174) that there was in this part of the century some preference given to nature. See also Jan Emmens, "Natuur, onderwijzing en oefening. Bij een drieluik van Gerrit Dou," Album discipulorum, aangeboden aan J. G. van Gelder ter gelegenheid van zijn zestigste verjaardag 27 Februari 1963., ed. Josua Bruyn et al. (Utrecht: Dekker \& Gumbert, 1963), 125-36.

${ }^{18}$ In his 1963 essay (see previous note), Emmens offers as a primary example an early eighteenth-century text: Arnold Houbraken's Groote schouburgh der Nederlantsche konstschilders en schilderessen (Amsterdam: printed by the author, 1718-21), specifically his biography of Michiel van Musscher (vol. 3, p. 5), which indeed attributes to Aristotle the following phrase: "Three things are needed to achieve learning: nature, teaching, and practice; but all will be fruitless unless practice follows nature and teaching." Emmens also cites Samuel van Hoogstraten's Inley- 
ding tot de hooge schoole der schilderkonst: anders de zichtbaere werelt (Rotterdam: François van Hoogstraten, 1678), 13-18, which does address all three concepts but nonetheless focuses on the opposition of nature and art. His only explicit seventeenth-century example is the poet Theodoor Rodenburg's Eglentiers poëtens borst-weringh of 1619, though he also follows Allan Ellenius, De Arte Pingendi, 73, in suggesting that the structure of the second book of Junius's Painting of the Ancients was inspired by this triad. Although Junius ends this book with a chapter on individual fame, noting as its ingredients "the divine gift of a prone and capable nature, the diligent care of parents and masters, the feare of wholesome lawes, the earnestnesse of emulating, the simplicitie and sweetnesse of these Arts," (Junius, The Painting of the Ancients, bk. 2, chapt. 14, sect. 1, p. 190), the main thrust is the development and periodic decline of painting as an art form in antiquity and the social and cultural factors that contributed to it.

${ }^{19}$ Jan Vos, Medea (Amsterdam: J. Lescailje, 1667). On Vos, see also Sluijter, Rembrandt and the Female Nude, 217.

${ }^{20}$ Andries Pels, Q. Horatius Flaccus dichtkunst op onze tijden en zeden gepast (Amsterdam: Jan Bouman, 1677).

${ }^{21}$ Ibid., 35-36.

${ }^{22}$ Ibid.

${ }^{23}$ Andries Pels, Gebruik, én misbruik des tooneels (Amsterdam: Albert Magnus, 1681).

${ }^{24}$ Constantijn Huygens, Mijn jeugd, trans. C. L. Heesakkers (Amsterdam, Em. Querido's Uitgeverij, 1987). The original Latin manuscript is in the Koninklijke Bibiotheek in The Hague (KW KA 48). For a discussion of these remarks, see Sluijter, Rembrandt and the Female Nude, 101-2.

${ }^{25}$ Huygens, Mijn jeugd, 42-43.

${ }^{26}$ Ibid., 85. The original Latin reads: "Ut suum cuique tribuam, nec alterum laedam tamen, (mea enim quid interest?) nihil praeceptoribus debent, ingenio omnia, ut, si nemine praeeunte relicti olim sibi fuissent et pingendi forte impetum cepissent, eodem evasuros fuisse persuadear, quo nunc, ut falso creditur, manu ducti adscenderunt."

${ }^{27}$ Nativel, "Le traité 'Du sublime," 725, also links Junius's "grace" to the Longinian sublime. On Samuel van Hoogstraten's similar use of the term and his own translation of the sublime as "waarlijk groot," see Weststeijn, The Visible World, 154-59, esp. 155 and 157. For the broader history of the term, with discussion of Junius's use of it, see Samuel Holt Monk, "A Grace Beyond the Reach of Art," Journal of the History of Ideas 5, no. 2 (April 1944): 131-50; and Richard E. Spear, The "Divine" Guido: Religion, Sex, Money and Art in the World of Guido Reni (New Haven and London: Yale University Press, 1997), 102-14. See also Nicola Courtright, "Origins and Meanings of Rembrandt's Late Drawing Style,” Art Bulletin 78, no. 3 (Sept. 1996): 485-510.

${ }^{28}$ Longinus, On the Sublime, chapt. 1, sect. 3, p. 2).

${ }^{29}$ On Longinus and the concept of genius, see Penelope Murray, "Poetic Genius and Its Classical Origins," in Genius: The History of an Idea, ed. Penelope Murray (Oxford: Basil Blackwell, 1989), 16-18; and M. H. Abrams, The Mirror and the Lamp: Romantic Theory and the Critical Tradition (London, Oxford, and New York: Oxford University Press, 1953), 72-78. On Junius and genius, see Nativel, "Le traité 'Du sublime," 723-25.

${ }^{30}$ Nativel, "Le traité 'Du sublime," 722, notes that Junius's discussion of nature and art derives in part from Longinus.

${ }^{31}$ Longinus, On the Sublime, chapt. 33, sect. 5, p. 64. Longinus refers here specifically to the Greek poet Archilochus, but as part of a passage in which Archilochus, Homer, Pindar, and Sophocles are all identified as writers whose god-gifted genius cannot be restrained by rules. 
${ }^{32}$ See Spear, The "Divine" Guido, 116-19, on the theological concept before and after the Reformation.

${ }^{33}$ C.S.M. Rademaker, "Young Franciscus Junius: 1591-1621," in Franciscus Junius F.F. and His Circle, ed. Rolf H. Bremmer Jr. (Amsterdam and Atlanta: Editions Rodopi, 1998), 13-14. Junius refused to takes side in the debate and was eventually forced to abandon his religious career.

${ }^{34}$ Translated in Peter Y. De Jong, Crisis in the Reformed Churches: Essays in Commemoration of the Great Synod of Dort (Grand Rapids, Mich.: Reformed Fellowship, 1968), 209-13.

${ }^{35}$ Monk, "A Grace Beyond the Reach of Art," 131-50.

${ }^{36}$ Baldassare Castiglione, Book of the Courtier, trans. Leonard Eckstein Opdycke (New York: Charles Scribner's Sons, 1903), 34.

${ }^{37}$ Ibid. See Monk, "A Grace Beyond the Reach of Art," 139-40, and Spear, The "Divine" Guido, 104.

${ }^{38}$ Cesare Ripa, Iconologia, overo Descrittione di diverse imagini cavate dallantichità, \& di propria inventione (Rome: Lepido Facii, 1603), 195. Translated and discussed by Monk, "A Grace Beyond the Reach of Art," 136. Junius echoes these words when he writes, in explicit reference to Longinus, that art, aided by perspicuity, "though shee doth ravish the minds and hearts of them that view her workes, yet doe they feel themselves violently carried away, but think themselves gently led to a liking of what they see." (Junius, Painting of the Ancients, bk. 1, chapt. 4, sect. 6, p. 58)

${ }^{39}$ Anthony Blunt, Artistic Theory in Italy, 1450-1600 (Oxford: Clarendon Press, 1940), 93-98.

${ }^{40}$ Translated and discussed by Blunt, Artistic Theory in Italy, 96.

${ }^{41}$ Junius, Painting of the Ancients, bk. 1, chapt. 3, sect. 8, p. 38.

${ }^{42}$ Longinus, On the Sublime, chapt. 1, sect. 3-4, pp. 2-3.

${ }^{43}$ Nativel, "Le traité 'Du sublime," 722-25.

${ }^{44}$ Junius, Painting of the Ancients, bk. 3, chapt. 6, sect. 2, p. 287. Discussed by Nativel, "Le traité 'Du sublime,"' 722.

${ }^{45}$ Junius, Painting of the Ancients, bk. 1, chapt. 4, sect. 1, p.44.

${ }^{46}$ Ibid., bk. 1, chapt. 4, sect. 1, pp. 45-46.

${ }^{47}$ Ibid., bk. 3, chapt. 1, sect. 15, pp. 219-20.

${ }^{48}$ Ibid.

${ }^{49}$ Ibid., bk. 3, chapt. 7, sect. 3, p. 297.

${ }^{50}$ Ibid., bk. 3, chapt. 6, sect. 1, p. 284.

${ }^{51}$ Ibid., bk. 3, chapt. 6, sect. 2, pp. 285-86.

${ }^{52}$ Ibid., bk. 3, chapt. 6 , sect. 3, pp. 287-88.

${ }^{53}$ Ibid., bk. 2, chapt. 11, sect. 7, p. 179. Discussed by Nativel, “Le traité 'Du sublime’ et la pensée esthétique anglaise," 725 . For this invocation of Longinus (who is explicitly named in Junius's

Latin edition), I also thank Wieneke Jansen, who is currently preparing an article on the reception of Longinus in the Netherlands in the seventeenth century for a forthcoming special issue of Lias. ${ }^{54}$ Junius, Painting of the Ancients, bk. 3, chapt. 6, sect. 6, pp. 292-93.

${ }^{55}$ Daniel Heinsius, De tragoediae constitutione liber, in quo inter caetera tota de hac Aristotelis sentential dilucide explicatur (Leiden: Ex officinâ Elsevirianâ, 1643); Gerardus Vossius, Poeticarum institutionum, libri tres (Amsterdam: Apud Ludovicum Elzevirium, 1647). See also Edith Kern, The Influence of Heinsius and Vossius upon French Dramatic Theory (Baltimore: Johns Hopkins Press, 1949).

${ }^{56}$ Mieke B. Smits-Veldt, Het Nederlandse renaissancetoneel (Utrecht: HES, 1991), 106, and Bettina Noak, "Vondel as a Dramatist: The Representation of Language and Body," in Joost van den Vondel 
(1587-1679): Dutch Playwright in the Golden Age, ed. Jan Bloemendal and Frans-Willem Korsten (Leiden and Boston: Brill, 2012), 117-18.

${ }^{57}$ See commentary by Jan Konst in his edition of Jan Six, Medea treurspel (Berlin: Freie Universität, 2000).

${ }^{58}$ Joost van den Vondel, J. v. Vondels poëzy of verscheide gedichten (Amsterdam: Joost Hartgers, 1650), and Vondel, Q. Horatius Flaccus, Lierzangen en dichtkunst (Amsterdam: Luidewijck Spillebout, 1654).

${ }^{59}$ For an alternative view, see Arie Gelderblom, "A Rejuvenating Corset: Literary Classicism in the Dutch Republic," in Dutch Classicism in Seventeenth Century Painting, ed. Albert Blankert, (Rotterdam: Boijmans Museum; Frankfurt: Städelsches Institut, 1999), 54-61.

${ }^{60}$ Amy Golahny, Rembrandt's Reading (Amsterdam: Amsterdam University Press, 2003), 123-25. See Deerste twaelf boecken Odysseae: Dat is, De Dolinghe van Ulysse, trans. D. Coornhert (Haarlem: Jan van Zuren, 1561; reprinted in Delft in 1593 and reissued numerous times); De tweede xii boecken Odysseae: Dat is, De Dolinge van Ulysse, trans. D. Coornhert (Amsterdam: Hendrick Barentsz, 1609); De eerste 12. boecken van de Ilyadas, trans. K. van Mander (Haarlem: Adr.

Rooman, 1611); De Dooling van Ulisses in 24 boecken, trans. G. van Staveren (Amsterdam: Gerrit van Goedesberg en Klaas Fransz.; in de drukkery van Tymon Houthaak,1651); De Iliaden van Homerus, trans. J. H. Glazemaker (Amsterdam: Jan Rieuwersz, 1654-58).

http://dx.doi.org/10.5117/9789053566091

${ }^{61}$ The Poetics of Aristotle, trans. S. H. Butcher (London and New York: Macmillan, 1895), 31, part 8 , and 83 , part 23 .

${ }^{62}$ Jonathan Bikker in Rembrandt: The Late Works, 217-18, similarly interprets Aristotle's expression as one of "divine ravishment" (enthousiasma).

${ }^{63}$ See Christian Tümpel, "Ikonographische Beiträge zu Rembrandt (I): Zur Deutung und Interpretation seiner Historien," Hamburg Jahrbuch 13 (1968): 95-106; and Tümpel, "Ikonographische Beiträge zu Rembrandt (II): Zur Deutung und Interpretation einzelner Werke," Hamburg Jahrbuch 17 (1971): 20-38.

${ }^{64}$ Many of them are depictions of the Old Testament figure Joseph, whose employment by Pharaoh does have negative implications of enslavement. See, for example, Arent de Gelder's Benjamin's Cup (Judah Pleading before Joseph), ca. 1680-85, The Hohenbuchau Collection.

${ }^{65}$ The idea that Rembrandt and his contemporaries mistook such representations of Minerva for likenesses of Alexander was first proposed by Konrad Kraft, "Der behelmte Alexander der Große," in Jahrbuch für Numismatik und Geldgeschichte 15 (1965): 7-8, and endorsed by Held, Rembrandt Studies, 31. Margaret Carroll, "Rembrandt's Aristotle: Exemplary Beholder," Artibus et Historiae 5, no 10 (1984): 49-50, esp. 45, argued against this, identifying the image on the medallion in the painting as Minerva and returning to the hypothesis first raised by Herbert von Einem that the chain represents the "golden chain of Homer," a metaphor for continuity across time and between the divine and earthly. See von Einem, "Rembrandt und Homerus," 187-89.

${ }^{66}$ Junius, Painting of the Ancients, bk. 3, chapt. 6, sect. 7, p. 294.

${ }^{67}$ Ibid.: "hoe onse vervrolickte herten door de helde van een verbaesde verwonderingh soetelick gevetert ende gevangen houdt."

${ }^{68}$ Salomon and Langdon, "Of Men and Mechanical Doves," 28.

${ }^{69}$ Ibid.

${ }^{70}$ Pels, Gebruik, én misbruik des tooneels, 36-37: “'t Moest al gevólgd zyn, óf natuur was niet te vréên;/Ten minsten zyne, die geen régels, nóch geen réden/Van évenmaatigheid gedoogde in 's 
ménschen léden." My translation is based largely on de Winkel, Fashion and Fancy, 195.

http://dx.doi.org/10.5117/9789053569177

${ }^{71}$ Ibid. The entire sentence reads: "Maar óch! hoe éd'ler geest, hoe meer zy zal verwild'ren,/Zo zy zich aan geen grond, én snoer van régels bindt,/Maar alles uit zich zélf te weeten onderwindt!" My translation is informed by that in Svetlana Alpers, Rembrandt's Enterprise: The Studio and the Market (Chicago: University of Chicago Press, 1988), 137-39n48.

${ }^{72}$ Longinus, On the Sublime, chapt. 33, sect. 4, p.64.

\section{Bibliography}

Abrams, M. H. The Mirror and the Lamp: Romantic Theory and the Critical Tradition. London, Oxford, and New York: Oxford University Press, 1953.

Alpers, Svetlana. Rembrandt's Enterprise: The Studio and the Market. Chicago: University of Chicago Press, 1988.

Aristotle. The Poetics of Aristotle. Translated by S. H. Butcher. London and New York: Macmillan, 1895.

Bikker, Jonathan, et al. Rembrandt: The Late Works. Exh. cat. London: National Gallery, and Amsterdam: Rijksmuseum, 2014.

Blankert, Albert, et al. Rembrandt: A Genius and His Impact. Exh. cat. Melbourne: National Gallery of Australia, and Sydney: Art Exhibitions Australia/Zwolle: Waanders, 1997.

Blunt, Anthony. Artistic Theory in Italy, 1450-1600. Oxford: Clarendon Press, 1940.

Carroll, Margaret. “Rembrandt's Aristotle: Exemplary Beholder." Artibus et Historiae 5, no. 10 (1984): 35-56.

Castiglione, Baldassare. Book of the Courtier. Translated by Leonard Eckstein Opdycke. New York: Charles Scribner's Sons, 1903.

Chapman, H. Perry. Rembrandt's Self-Portraits: A Study in Seventeenth-Century Identity. Princeton, N.J.: Princeton University Press, 1990.

. "Rembrandt, Van Gogh: Rivalry and Emulation." In Rembrandt: Three Faces of the

Master, exh. cat., edited by Benedict Leca, 17-49. Cincinnati: Cincinnati Art Museum, 2008.

Courtright, Nicola. "Origins and Meanings of Rembrandt's Late Drawing Style." Art Bulletin 78, no. 3 (Sept. 1996): 485-510.

Crenshaw, Paul. Rembrandt's Bankruptcy: The Artist, His Patrons, and the Art Market in Seventeenth-Century Netherlands. Cambridge: Cambridge University Press, 2006. 
De Jong, Peter Y. Crisis in the Reformed Churches: Essays in Commemoration of the Great Synod of Dort. Grand Rapids, Mich.: Reformed Fellowship, 1968.

Dundas, Judith. "Franciscus Junius's 'The Painting of the Ancients' and the Painted Poetry of Ovid." International Journal of the Classical Tradition 3, no. 2 (Fall 1996): 159-70.

. Sidney and Junius on Poetry and Painting: From the Margins to the Center. Newark: University of Delaware Press, 2007.

Eck, Caroline van; Delbeke, Maarten; Bussels, Stijn; Pieters, Jürgen eds. Translations of the Sublime: The Early Modern Reception and Dissemination of the Peri Hupsous in Rhetoric, the Visual Arts, Architecture and the Theater. Leiden and Boston: Brill, 2012.

Einem, Herbert von. "Rembrandt und Homerus." Wallraf-Richartz-Jahrbuch 14 (1952): 182-205.

Ellenius, Allan. De Arte Pingendi: Latin Art Literature in Seventeenth-Century Sweden and Its International Background. Uppsala and Stockholm: Almqvist \& Wiksell, 1960.

Emmens, Jan. "Natuur, onderwijzing en oefening. Bij een drieluik van Gerrit Dou.” In Album discipulorum, aangeboden aan J. G. van Gelder ter gelegenheid van zijn zestigste verjaardag 27 Februari 1963, edited by Josua Bruyn et al., 125-36. Utrecht: Dekker \& Gumbert, 1963. . Rembrandt en de regels van de kunst. Utrecht: Dekker \& Gumbert, 1968.

Gelderblom, Arie. "A Rejuvenating Corset: Literary Classicism in the Dutch Republic.” In Dutch Classicism in Seventeenth Century Painting, edited by Albert Blankert, 54-61. Rotterdam: NAi Publishers, 1999.

Giltaij, Jeroen. Ruffo en Rembrandt: Over een Siciliaanse verzamelaar in de zeventiende eeuw die drie schilderijen bij Rembrandt bestelde. Zutphen: Walburg Pers, 1999.

Golahny, Amy. Rembrandt's Reading: The Artist's Bookshelf of Ancient Poetry and History. Amsterdam: Amsterdam University Press, 2003. http://dx.doi.org/10.5117/9789053566091

Heinsius, Daniel. De tragoediae constitutione liber, in quo inter caetera tota de hac Aristotelis sentential dilucide explicatur. Leiden: Ex officinâ Elsevirianâ, 1643.

Held, Julius S. Rembrandt Studies. Originally published as Rembrandt's Aristotle and Other Rembrandt Studies, 1969. Princeton, N.J.: Princeton University Press, 1991.

Hoogewerff, G. J. “Rembrandt en een Italiaansche Maecenas.” Oud Holland 35 (1917): 129-48.

Hoogstraten, Samuel van. Inleyding tot de hooge schoole der schilderkonst: anders de zichtbaere werelt. Rotterdam: François van Hoogstraten, 1678. 
Houbraken, Arnold. De groote schouburgh der Nederlantsche konstschilders en schilderessen. 3 vols. Amsterdam: printed by the author, 1718-21.

Huygens, Constantijn. Mijn jeugd. Translated by C. L. Heesakkers. Amsterdam: Em. Querido’s Uitgeverij, 1987.

Jongh, Eddy de. "Review of Hollandse schilders in the gouden eeuw by Bob Haak." Simiolus 15, no. 1 (1985): 65-68.

Jongkees, Jan Hendrik. Fulvio Orsini's Imagines and the Portrait of Aristotle. Groningen: J. B. Wolters, 1960.

Junius, Franciscus. De pictura veterum. Amsterdam: Johannes Blaeu, 1637.

. The Painting of the Ancients: De pictura veterum, according to the English Translation (1638). Vol. 1 of The Literature of Classical Art. Edited by Keith Aldrich, Philipp Fehl, and Raina Fehl. Berkeley, Los Angeles, and Oxford: University of California Press, 1991.

man, 1641.

. De schilder-konst der Oude, begrepen in drie boecken. Middelburg: Zacharias Ro-

Kern, Edith. The Influence of Heinsius and Vossius upon French Dramatic Theory. Baltimore: Johns Hopkins Press, 1949.

Kraft, Konrad. "Der behelmte Alexander der Große.” Jahrbuch für Numismatik und Geldgeschichte 15 (1965): 7-32.

Liedtke, Walter. “The Meanings of Rembrandt's Aristotle with a Bust of Homer." In Collected Opinions: Essays on Netherlandish Art in Honour of Alfred Bader, edited by Volker Manuth and Axel Rüger, 72-87. London: Paul Holberton, 2004.

. Dutch Paintings in the Metropolitan Museum of Art. New York: Metropolitan Museum of Art/New Haven and London: Yale University Press, 2007.

Longinus. On the Sublime. Translated by H. L. Havell. London: Macmillan, 1890.

Monk, Samuel Holt. "A Grace Beyond the Reach of Art." Journal of the History of Ideas 5, no. 2 (April 1944): 131-50.

Murray, Penelope. "Poetic Genius and its Classical Origins." In Genius: The History of an Idea, edited by Penelope Murray, 9-31. Oxford: Basil Blackwell, 1989.

Nativel, Colette. "Le Traité 'Du sublime' et la pensée esthétique anglaise de Junius à Reynolds." In Acta conventus neo-latini hafniensis: Proceedings of the Eighth International Congress of Neo-Latin Studies, Copenhagen, 12-17 August 1991, edited by Rhoda Schnur, 721-30. Bingham- 
ton, N.Y.: Medieval and Renaissance Texts and Studies, 1994.

Noak, Bettina. "Vondel as a Dramatist: The Representation of Language and Body." In Joost van den Vondel (1587-1679): Dutch Playwright in the Golden Age, edited by Jan Bloemendal and Frans-Willem Korsten, 115-38. Leiden and Boston, Brill, 2012.

Pels, Andries. Q. Horatius Flaccus dichtkunst op onze tijden en zeden gepast. Amsterdam: Jan Bouman, 1677. . Gebruik, én misbruik des tooneels. Amsterdam: Albert Magnus, 1681.

Rademaker, C. S. M. “Young Franciscus Junius: 1591-1621.” In Franciscus Junius F.F. and His Circle, edited by Rolf H. Bremmer Jr., 1-17. Amsterdam and Atlanta: Editions Rodopi B.V., 1998.

Ripa, Cesare. Iconologia, overo Descrittione di diverse imagini cavate dall'antichità, \& di propria inventione. Rome: Lepido Facii, 1603.

Salomon, Xavier F., and Helen Langdon. "Of Men and Mechanical Doves: Salvator Rosa's Archytas for Antonio Ruffo." Boletín del Museo del Prado 28, no. 46 (2010): 22-38.

Sandrart, Joachim von. L’Academia Todesca della Architectura, Scultura \& Pittura: Oder Teutsche Academie der edlen Bau-, Bild-, und Mahlery-Künste. 3 vols. Nuremburg: Jacob Sandrart; Frankfurt: Matthaei Merians; printed by Johann-Philipp Miltenberger, 1675.

Schwartz, Gary. Rembrandt, His Life, His Paintings: A New Biography with All Accessible Paintings Illustrated in Color. New York: Viking, 1985.

Six, Jan. Medea treurspel. Edited by Jan Konst. Berlin: Freie Universität, 2000.

Sluijter, Eric Jan. "Rembrandt and the Rules of Art Revisited." Jahrbuch der Berliner Museen 51 (2009): 121-29. . Rembrandt and the Female Nude. Amsterdam: Amsterdam University Press, 2006.

Smits-Veldt, Mieke B. Het Nederlandse renaissancetoneel. Utrecht: HES, 1991.

Spear, Richard E. The "Divine" Guido: Religion, Sex, Money and Art in the World of Guido Reni. New Haven and London: Yale University Press, 1997.

Thiel, Pieter J.J. van. Rembrandt 1669/1969. Exh. cat. Amsterdam: Rijksmuseum, 1969.

Tümpel, Christian. "Ikonographische Beiträge zu Rembrandt (I): Zur Deutung und Interpretation seiner Historien.” Hamburg Jahrbuch 13 (1968): 95-106.

. "Ikonographische Beiträge zu Rembrandt (II): Zur Deutung und Interpretation einzel- 
ner Werke." Hamburg Jahrbuch 17 (1971): 20-38.

Vondel, Joost van den. J. v. Vondels poëzy of verscheide gedichten. Amsterdam: Joost Hartgers, 1650 .

bout, 1654 .

, trans. Q. Horatius Flaccus, Lierzangen en dichtkunst. Amsterdam: Luidewijck Spille-

Vos, Jan. Medea. Amsterdam: J. Lescailje, 1667.

Vossius, Gerardus. Poeticarum institutionum, libri tres. Originally published 1647. Translated and edited by Jan Bloemendal in collaboration with Edwin Rabbie. Leiden and Boston: Brill, 2010.

Weststeijn, Thijs. The Visible World: Samuel van Hoogstraten's Art Theory and the Legitimation of Painting in the Dutch Golden Age. Translated by Beverley Jackson and Lynne Richards. Amsterdam: Amsterdam University Press, 2008.

. Art and Antiquity in the Netherlands and Britain: The Vernacular Arcadia of Franciscus Junius (1591-1677). Leiden and Boston: Brill, 2015. http://dx.doi.org/10.1163/9789004283992

Wetering, Ernst van de. Rembrandt: The Painter at Work. Revised ed. Berkeley and Los Angeles: University of California Press, 2009.

. A Corpus of Rembrandt Paintings VI: Rembrandt's Paintings Revisited-A Complete Survey. Dordrecht: Springer, 2014.

Winkel, Marieke de. Fashion and Fancy: Dress and Meaning in Rembrandt's Paintings. Amsterdam: Amsterdam University Press, 2006. http://dx.doi.org/10.5117/9789053569177 